\title{
Correction to: Imaging plant responses to water deficit using electrical resistivity tomography
}

\author{
Sathyanarayan Rao (D) Nolwenn Lesparre • Adrián \\ Flores-Orozco • Florian Wagner • Andreas Kemna • \\ Mathieu Javaux
}

Received: 27 August 2020 / Accepted: 27 August 2020

(C) The Author(s) 2020, corrected publication 2020

\section{Correction to: Plant Soil \\ https://doi.org/10.1007/s11104-020-04653-7}

The original version of this article unfortunately contained a mistake. The authors would like to add Andreas Kemna as the fifth author of this paper. The updated list of authors as well as the complete affiliation is presented in this correction article.

The original article has been corrected.

Open Access This article is licensed under a Creative Commons Attribution 4.0 International License, which permits use, sharing, adaptation, distribution and reproduction in any medium or format, as long as you give appropriate credit to the original author(s) and

The online version of the original article can be found at https://oi. org/10.1007/s11104-020-04653-7

\section{S. Rao $(\bowtie) \cdot$ M. Javaux}

Department of Environmental Sciences, Earth and Life Institute, Université Catholique de Louvain, Louvain-la-Neuve, Belgium e-mail: Sathyanarayan.rao@uclouvain.be

\section{N. Lesparre}

Laboratoire d'Hydrologie et Géochimie de Strasbourg, University of Strasbourg/EOST/ENGEES, CNRS UMR7517, 1 Rue Blessig, 67084 Strasbourg, France

\section{A. Flores-Orozco}

Geophysics Research Group, Vienna University of Technology, Gusshausstraße 27-29, E120-3, 1040 Vienna, Austria the source, provide a link to the Creative Commons licence, and indicate if changes were made. The images or other third party material in this article are included in the article's Creative Commons licence, unless indicated otherwise in a credit line to the material. If material is not included in the article's Creative Commons licence and your intended use is not permitted by statutory regulation or exceeds the permitted use, you will need to obtain permission directly from the copyright holder. To view a copy of this licence, visit http://creativecommons.org/licenses/by/4.0/.

Publisher's note Springer Nature remains neutral with regard to jurisdictional claims in published maps and institutional affiliations.
F. Wagner

Institute for Applied Geophysics and Geothermal Energy, RWTH Aachen University, Aachen, Germany

\section{A. Kemna}

Geophysics Section, Institute of Geosciences, University of Bonn, Bonn, Germany

M. Javaux

Agrosphere, IBG3, Forschungszentrum Jülich GmbH, Jülich, Germany 